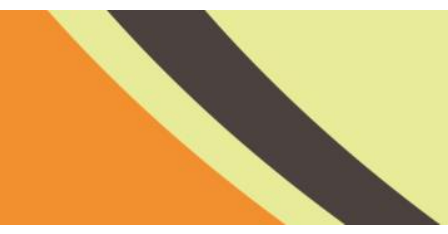

\title{
Economic Analysis of Applying Biomass Stove to Produce Hot Water Serving Child Development Center: The Case Study of Omkoi District, Chiangmai, Thailand
}

\author{
Chulasak, R., Phothachareon,W., Sawatdeenarunat, $C .{ }^{l}$ \\ ${ }^{I}$ Asian Development College for Community Economy and Technology, Chiang Mai Rajabhat University, Chiang Mai, Thailand \\ Corresponding author: chayanon@cmru.ac.th
}

\begin{tabular}{|c|}
\hline ARTICLE INFO \\
\hline $\begin{array}{l}\text { Article History: } \\
\text { Received: July 29, } 2019 \\
\text { Final Revision: November 24, } 2019 \\
\text { Available Online: December 22, } 2019\end{array}$ \\
\hline KEYWORDS \\
\hline $\begin{array}{l}\text { techno-economic analysis, hot water, hybrid } \\
\text { biomass stove, Child Development Center }\end{array}$ \\
\hline CORRESPONDING AUTHOR \\
\hline
\end{tabular}

\section{INTRODUCTION}

There are various technics to simultaneously generate bioenergy as and reduce wasted biomass in communities. Biomass stove is one of the promising tools to convert biomass such as agricultural and forestry wastes to energy for not only replacing LPG (Liquefied Petroleum GAS) for cooking but also to generating hot water. By installing heat exchanger to the stack of the stove, the heat from the combustions can convert the supplied water to hot water for further utilization. The survey reported that there are 67 tons of wood chips and agricultural wastes produced daily in Omkoi district. These materials could be used as the feedstock for the biomass stove and thermochemically converted to the energy with of $850 \mathrm{MJ} / \mathrm{d}$.[1]

Child Development Center (CDC), typically, needs water for serving many activities including but are not limited to children bathing, laundering, and cleaning milk bottles and utensils. Those activities are necessary for preventing the children from many diseases such as dermatosis and diarrhea. Besides, weather in Omkoi district is generally cold all year round (i.e. average temperature during morning is between $15-20{ }^{\circ} \mathrm{C}$ ). Therefore, hot water generation is essential for enhancing the hygienic of the student in CDC. Regarding to the aforementioned statements, hybrid biomass stove is suitable waste-to-energy tool for serving CDC. In addition, the biomass stove could simultaneously help reducing electricity cost for heater and reducing the accumulated wasted biomass in the community. This research aims to perform the techno-economic of applying biomass stove to the CDC in Omkoi sub-district, Chiang Mai, Thailand.

\section{MATERIALS AND METHODS}

The research was performed with respect to the flow chart as presented in Figure 1.

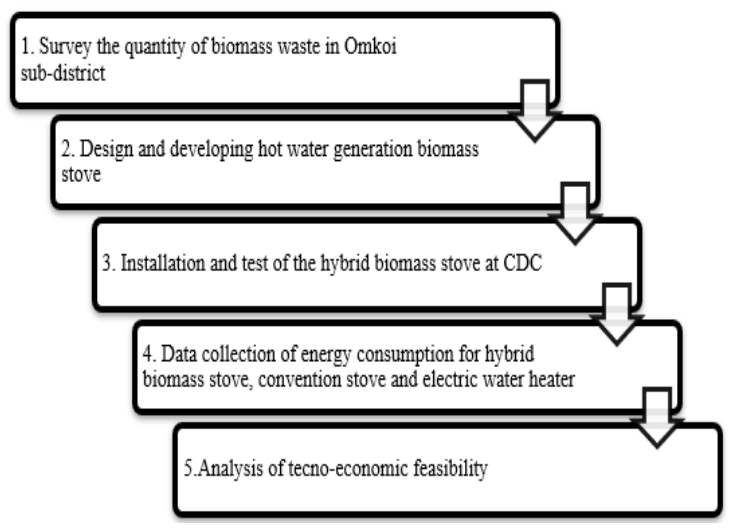

Figure 1. Schematic of the research methodology 
The Hybrid biomass stove was designed and installed with heat exchanger on the top of the stove's stack. The heat exchanger is a device used to transfer thermal energy between two or more fluids, which are at different temperatures. Thus, the heat exchanger recovered the exhausted heat with more $400^{\circ} \mathrm{C}$ from the biomass burning in the chamber to producing hot water around $65-90{ }^{\circ} \mathrm{C}$ with $100-180$ liters per hour by utilizing 30 Kilograms plant/agriculture waste as the fuel.

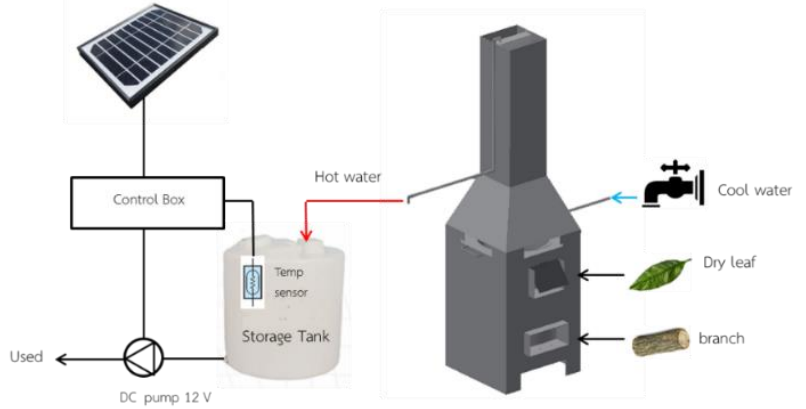

Figure 2. Hybrid biomass stove system

The combustion efficiency of biomass stove is higher than that of the conventional stove with respect to the appropriate air to fuel ratio. Thus, lower air pollution and smoke were generated. Thus, it could definitely help mitigating the air pollution. The boundary of the manuscript is to evaluate the tecno-economic analysis of the CDC contains 35 Childs. The assumptions of economic analysis are presented below.

Net present value (NPV), Internal rate of return (IRR) and Pay Back Period (PBP) were analyzed for Techno-economic assessment (TEA) [2] within conditions like

The project lifetime is 3 years.

The core inflation rate is $0.6 \%$. [3]

Expense are from the cost reducing from replacing LPG and electricity

The required hot water at least 100 liters per day with temperature at $65^{\circ} \mathrm{C}$

The economic analyzing of the 2 scenarios were performed:

Using biomass stove to replace conventional stove using LPG

Using biomass stove to replace conventional stove using electric water heater

\section{RESULT AND DISCUSSION}

The results from the field survey indicated that the monthly LPG consumption for producing hot water was $30 \mathrm{~kg}$. The 4,500-watts electrical heater was used as a supplemental hot water generation unit for 2 hours/day. The appropriate biomass stove serving this $\mathrm{CDC}$ is the stove with the capacity of $30 \mathrm{~kg}$ of biomass feeding.

The calculated energy content of fuel (net calorific value) indicated that $30 \mathrm{~kg}$ of wood chips contain the energy of 479.70 MJ which could replace LPG of $9.73 \mathrm{~kg}$ and $133.25 \mathrm{kWh}$ for electricity [1].

The Economical parameters as NPV, IRR and PBP were analysed as the Table 2 .

Table 2. Result of economic analysis for scenario 1

\begin{tabular}{|l|c|c|c|c|}
\hline \multirow{2}{*}{$\begin{array}{l}\text { Hot water } \\
\text { source }\end{array}$} & \multirow{2}{*}{$\begin{array}{c}\text { Expense } \\
\text { cost: } \\
\text { LPG } \\
\text { (baht) }\end{array}$} & \multicolumn{3}{|c|}{ Economical parameters } \\
\cline { 3 - 5 } & NPV & IRR & PBP \\
\hline $\begin{array}{l}\text { Convention } \\
\text { stove using } \\
\text { LPG }\end{array}$ & 11,400 & 835 & $8 \%$ & 2.58 \\
\hline
\end{tabular}

The result of Convention stove replacement was NPV of 835 THB, IRR was $8 \%$ and PBP was 2 years and 5 months.

Table 1. Result of economic analysis for scenario 2

\begin{tabular}{|c|c|c|c|c|}
\hline \multirow{2}{*}{$\begin{array}{l}\text { Hot water } \\
\text { source }\end{array}$} & \multirow{2}{*}{$\begin{array}{l}\text { Expense } \\
\text { cost: } \\
\text { electricity } \\
\text { (baht) }\end{array}$} & \multicolumn{3}{|c|}{ Economical parameters } \\
\hline & & NPV & IRR & PBP \\
\hline $\begin{array}{l}\text { Electric } \\
\text { water } \\
\text { heater }\end{array}$ & 8,712 & 5,850 & $24 \%$ & 1.97 \\
\hline
\end{tabular}

And the result of Electric water heater was NPV of 5,850 THB, IRR was $24 \%$ and PBP was 2 years.

When considering of Economical parameters i.e NPV, IRR and PBP, Using the hybrid biomass stove to produce hot water replacing the conventional energy are feasible for both scenarios with respect to the positive NPV. However, the scenario 2 has higher IRR and lower PBP. Thus, based on the assumptions, the biomass stove should be used for producing hot water replacing electric water heater.

\section{CONCLUSION}

According to the study, it can be concluded that Hybrid biomass stove could potentially replace convention stove using LPG and electrical water heater for producing hot water serving CDC. Applying hybrid biomass stove could help decreasing LPG usage and enhance the household economics and it can be considered as the solution for managing the wasted biomass from agricultural activities of the communities which is normally burnt during the land preparation. The open burning of the agricultural residues is one of the important sources of the annual severe air pollution in the northern Thailand. Thus, by converting the waste biomass to hot water could simultaneously enhance the energy security of the community and mitigate the environmental issues.

\section{AKNOWLEDGEMENT}

Thanks to NRCT for the research funding. The authors also thank Omkoi village and Omkoi Sub-district administrative organization for the collaboration.

\section{REFERENCE}

[1] Department of Alternative Energy Development and Efficiency. (2019, September 2). Biomass. Retrieved from http://www2.dede.go.th/renew/bio_p.htm

[2] Maximilian Lauer. Methodology guideline on techno economic assessment (TEA). Generated in the Framework of ThernalNet WP3B Economics. IEA Bioenergy.

[3] Bank of Thailand. (2019, September 11). Forcast Summary. Retrieved from https://www.bot.or.th/English/MonetaryPolicy/MonetPolicy Comittee/MPR/Pages/default.aspx. 